that is ultimately highly personal" (p. 193), the themes that emerged, underpinning her understanding of criminal organization and confederacy, were: expanding print culture; the interactions between the public and the publicity of crime; and the evolution of networks and territory. What the book offers is a series of "snapshots, moments and episodes in the making of the modern underworld" (p. 193), an underworld that does not exist, but is constructed, and whose discursive power acts as a shorthand for commentators who sought "to describe the worlds of the criminal, deviant and the poor, and to keep them at arm's length” (p. 195).

This, then, is a very interesting book, drawing on the digitization of the Old Bailey records and other archival and published sources. At times, its arguments seem somewhat elusive, and the emphasis on print culture, criminal networks, and criminal territory slightly repetitive. Some sections offer empirical narratives that are overly detailed, and there is no sustained exploration of the "criminal class". While Shore employs a long time-frame, whether the events of the I720s or the I 920 s were a case of a break from the past, or of continuity, remains unclear. And as the author is the first to admit, the book relies heavily on the records of the Old Bailey, so we hear much less about the experience of other cities. Nevertheless, the basic premise of the book - that the underworld was both a cultural and a social construct - is an appropriate one, and the case study approach offers one way of revealing its overlapping communities. While actual levels of crime in working-class neighbourhoods are not reconstructed here, and probably cannot be, this book goes far towards mapping the changing contours of London's criminal underworlds.

\title{
John Welshman
}

Department of History, Bowland College, Lancaster University Lancaster LA I 4 YT, United Kingdom E-mail: j.welshman@lancaster.ac.uk

Towards a Global History of Domestic and Caregiving Workers. Ed. by Dirk Hoerder, Elise van Nederveen Meerkerk and Silke Neunsinger. [Studies in Global Social History, Vol.r8; Studies in Global Migration

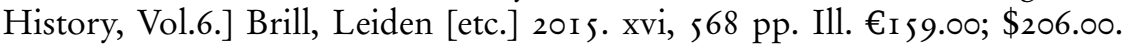
doi: $10.1017 /$ S0020859016000I 34

There can be no doubt that one of the most significant developments during the last three decades has been the rise of an international movement of mostly migrant domestic workers. This is especially remarkable considering that it has risen in the midst of the decline of working-class activism in Europe and the US. So impressive have been their organizational capacity and the transnational networks that they have created that, in 201 I, the International Labour Organization (ILO) decided, after much deliberation, to extend to them the protections in principle guaranteed to workers in the so-called "formal economy". The increasing presence of migrant domestic workers, many of them women of color, in towns across the world, has also stimulated new debates among feminist activists and scholars about the crisis of care work, which the neo-liberal turn has produced, as well as the hardships these workers are facing and the possibility of alternatives to this form of employment. 
It is against this background that we must consider the publication of Towards a Global History of Domestic and Caregiving Workers (in the following Towards a Global History), the latest contribution to the growing body of literature produced on this topic in recent years. The book, however, stands out for many reasons. First, while most recent literature is written from a feminist viewpoint, Towards a Global History also has a strong labor perspective. Indeed, one of the book's main objectives is to contribute to making labor history more inclusive, extending its reach beyond its traditional concentration on usually white, male industrial workers. Towards a Global History is also a committed effort to a non-Eurocentric viewpoint, with most of its essays focusing on Africa, Asia, Latin America, and the European "periphery". Not last, it is far more ambitious in its aims than most contemporary studies. Like the conference that inspired it, ${ }^{\mathrm{I}}$ the book gathers an impressive array of scholars, coming from different parts of the world, all experts in the field.

Furthermore, while most contemporary studies examine one country or one aspect of domestic work and focus on the present, Towards a Global History travels through space and time, with articles, as mentioned, drawn from every continent, covering a period of at least two centuries. This is not an accident. For the main argument and organizational principle of the book is that historicizing domestic work enables us not only to better grasp the complex nature of this kind of work, but to rethink the frameworks used by scholarly literature, past and present, and correct some of its presumptions.

For this purpose, the book includes a substantial historiographical section that examines the main changes in the paradigms that scholars have utilized to analyze domestic work. Placed at the beginning of the book, it warns us against hasty theorizations, showing that, starting in the later part of the nineteenth century, social theorists began to predict the end of domestic work, a view that after World War II had become canonic (pp.3 I-32). Why, rather than disappearing, this work has revived in the I980s and I990s, and has since expanded in almost every country worldwide, is a question that none of the contributors explicitly addresses, though the most current theories on the subject are often cited. This, too, is no accident. For what the book strives to demonstrate is that, viewed from a historical and global perspective, patterns that in the current literature are considered specific to the contemporary trends turn out to be expansions of "old arrangements" (p.55).

Given the historic transformations to which the "globalization of domestic work" has responded, this is a thesis that will be undoubtedly debated, as it can be argued that the return of domestic work in the I980s and I990s has been part of a global restructuring of reproductive work that seems unique in its extent and purposes. This, however, does not diminish the significance of the effort that animates the book. For the rich and diverse historical reconstructions it assembles in support of the continuity thesis help us identify some of the main structural constraints that have shaped domestic work over time into the present.

Various essays show, for example, that migration (from rural to urban as well as across borders) and even separation from one's families, has long been associated with domestic work, as a means of escape from marginalization or of entry into more affluent societies and, from the employers' viewpoint, a means of "othering" and deliberate estrangement. Exemplary here are the cases of the Slovenian women cited by Majda Herzenjak, who, for more than a century,

I. "Towards a Global History of Domestic Workers and Caregivers", 49th Conference of the ITH - International Conference of Labour and Social History, I2-Is September 2013, Linz, Austria, http://ith.or.at/konf_e/49_index_e.htm. 
despite regime changes, have crossed the Italian border to work in the homes of Trieste's middle class or even migrated to Egypt for many consecutive years. Equally paradigmatic are the experiences of the Filipinas (studied by Yukari Takai and Mary Gene de Guzman) who migrate to Canada to improve their families' conditions, only to discover that they can never return home, and of the Yemeni upper-class employers, who (in Marina de Regt's article) prefer migrant workers as it is easier to maintain an emotional distance with them.

As structural as migration - a historical approach demonstrates - is the long-standing relation between domestic work, servitude, and enslavement. This is well documented by Elizabeth Hordge-Freeman and Jaira J. Harrington's article on domestic workers in Brazil and R. David Goodman's on Morocco, both illustrating the legacy of slavery and its reconfiguration in the twentieth century, and Magali Rodríguez García's discussion of the difficulties hindering the eradication of child slavery in Hong Kong, a practice which could, more often than not, count on the toleration of the British colonial authorities.

More broadly, what Towards a Global History convincingly demonstrates is that the ambivalence and contradictions that today characterize the situation of domestic workers have long been inherent to the organization of this work. For, on the one hand, domestic work has always been a source of degradation as an activity presumably unskilled, "impure", frequently associated, as we have seen, with slavery and racialized; on the other, it has historically represented one of the few options for women of economic independence, often providing an escape from oppressive families and the claustrophobic relations often typical of village life. Similarly, in contrast to narratives stressing victimization and alongside the cited evidence that domestic work requires a process of "othering" and subordination, the book also argues that this has not been incompatible with affective relations and role reversals.

In this context, one of the most interesting parts of the book is that which explores the role of domestic work in the formation of empire - a topic understudied and yet crucial, considering the acknowledged continuity between colonization and globalization. Domestic workers, often males, were the backbone of life in the colonies, playing multiple roles, as upholders of the colonial authorities' social status as well as cultural intermediaries teaching the male colonial administrators the politics of place, even becoming confidants at times in a complex relation challenging the monochromatic image of the master-servant encounter in anti-colonial literature. As argued by Robyn Allyce Parise's essay "African Servants and the Making of European Domesticity in Tanganika”, despite its frequently violent character, relations between colonizers and their domestics left space for intimacy and affection, as well as role reversals, as when the "servants" unfavorably judged their employers, applying their own cultural standards to their performance. Nevertheless, colonialism so deeply transformed the colonized lives and cultures that its history continues to structure migration patterns and global labor relations, as well as the self-presentation of domestic workers from the former colonies, recreating the bonds of the past and extending to their descendants the inequalities between colonizers and colonized. This phenomenon is well evinced by Sabrina Marchetti's effective study of the narratives of Afro-Surinamese and Ethiopian workers, both directing their steps to the former colonizers of their regions, confident in the advantage the knowledge of (respectively) Dutch and Italian culture provides them (pp. $366 \mathrm{ff}$.).

Committed to stressing the agency of domestic workers, Towards a Global History analyses the strategies they have adopted to break with their subordination, reporting on forms of mobilization that are of special value today as the question of collective action and organization (especially in the form of union-based self-organizing,) is of key importance for the domestic workers' movement. It is interesting, for instance, to discover in Elizabeth Quay Hutchinson's discussion of domestic workers in Chile that here, already in the I920s, they 
were fighting for inclusion in labor legislation, obtaining that labor inspectors make visits to private homes and other compensatory mechanisms, paving the way to more serious reforms in the I940s. This is even more surprising as we find, in Jessica Richter's essay on labor debates in interwar Austria, how reluctant governments have been to regulate domestic work and even recognize it as real work. The issue is further complicated by testimonies indicating that while, for some workers, state regulation is a path to autonomy and freedom, for others it is not always the preferable solution. Readers will be surprised to hear that in post-apartheid South Africa, for instance, some domestic workers prefer the intensely personal relations that prevailed in the previously unregulated context, to the standardized model adopted after the demise of apartheid, which presumably left less space to personal favors and negotiations or even simply to the satisfaction derived from the drama provided by interpersonal relations. The lesson here is that no less than the work itself, the struggle for more equitable relations takes many forms and the road to its recognition is never a straight line.

Other histories are examined by the book that add to its importance. There are limits, however, to the methodological approach Towards a Global History has taken that, ostensibly, a sequel will correct. The most significant is that its theoretical approach gives no space to the relation between paid and unpaid domestic labor and the place and function of reproductive labor in the capitalist organization of production, choosing "coloniality", instead, as the relevant social and political framework within which domestic relations are analysed.

When introducing the book, the editors are careful to define domestic work as "work in the households of others" (p. 2), and their choice is sustained by the fact that most articles focus on service in upper-class families, where the "madams" are not expected to perform any domestic work. Still, the separation between paid and unpaid domestic work limits the book's vision and leaves crucial questions unanswered.

It is hard, for example, to understand what has motivated the revival of domestic labor in our time if we do not acknowledge women's revolt against housework in the I970s, which, in addition to a massive migration into waged work, also spawned a wages-for-housework movement and feminist critiques of the then thriving labor history that preceded by decades the work of unionists and scholars.

Integrating the histories of paid and unpaid domestic work, as continuous, "consubstantial" moments in women's lives, would also add to our understanding of long-term historical trends, such as the decline of paid domestic work in Europe in the last two decades of the nineteenth century, which can be attributed not only to the increasing preference by working-class women for factory work, as some authors claim, but to the development of the full-time housewife in the working class, made possible by the introduction of the "family wage". It would also enable us to recognize that the key function of domestic work in the capitalist organization of production and, ultimately, the reason of its productivity, which the editors acknowledge (p. 4, I7), but do not satisfactorily account for, is not the reproduction of the elite but the reproduction of the labor-force, to which paid domestic workers today contribute in no insignificant proportion. This is important as it may explain why domestic work in all forms - still the cheapest way to reproduce labor power - has survived many phases of "modernization". Finally, it is arguable that no major change in the condition of paid domestic workers will be possible as long as millions of women continue to provide the same work for free and a broad-based movement does not emerge uniting paid and unpaid workers. As of now, no such movement is on the horizon; on the contrary, the trend is towards specialization and professionalization. Thus, to call or imagine a "united front" between paid and unpaid worker may seem an idle proposition. Yet, as Raffaela Sarti admits - when she suggests that a universal extension of rights may not 
be not sufficient and that reducing the number of domestic workers should be a goal for policymakers (p.25) - paid domestic labor is an unstable solution to the question of reproduction (p. 59) given the high price that so many women pay for it.

Presently, however, as the excellent article by Eileen Boris and Jennifer Fish on the ILO treatment of domestic work demonstrates, it is paid domestic workers who are "on the move”, organizing in ways that revalorize domestic work and force unions, employers, and national and international institutions to revise their deep-seated assumptions about this work. To them, and their feminist and labor supporters, as well as sociologists and social historians, Towards a Global History is an extremely valuable reference point, as a methodological model and treasure trove of histories, insights, and not last bibliographical references. Still, a global history of paid domestic work will have to broaden its boundaries to include its unpaid counterpart. This, in my view, is the "new interpretative framework" that, in her essay on historian, social scientists and domestic workers, Raffaella Sarti calls for.

\section{Silvia Federici}

Hofstra University, Hempstead, New York I Plaza Street, Apt ${ }_{3}$ C, Brooklyn, New York, i 2 1 7 , USA E-mail: Silvia.Federici@Hofstra.edu

Baer, James A. Anarchist Immigrants in Spain and Argentina. University of Illinois Press, Urbana (IL) [etc.] 201 5. xviii, 240 pp. Ill. \$5 5.00. doi: I0.1017/ So0208590I6000I 46

Tomchuk, Travis. Transnational Radicals. Italian Anarchists in Canada and the U.S. 19 I 5-1940. University of Manitoba Press, Winnipeg 20 I 5. xi, $260 \mathrm{pp}$. Ill. \$27.95. (EPUB E-book: \$20.00; PDF E-book \$20.00.) doi: 10.1017/ So020859016000158

Zimmer, KenYon. Immigrants against the State. Yiddish and Italian Anarchism in America. [The Working Class in American History.] University of Illinois Press, Urbana [etc.] 201 5. x, 300 pp. Ill. \$95.00. (Paper: \$30.00.) doi: I0.1017/S002085901600016X

The three titles under review examine anarchism in a trans-Atlantic context. All three focus principally on migrants to the Americas from Europe. James Baer makes a valiant attempt to study the dynamic exchange of anarchist migrants between Argentina and Spain, while Travis Tomchuk and Kenyon Zimmer focus on immigrants to English-speaking North America. The approach of examining anarchism through a transnational analysis is a useful one. All three authors demonstrate the importance of networks and the fundamental role played by the "imagined communities" created by anarchists (though surprisingly, only Zimmer cites both Imagined Communities and Under Three Flags by Benedict Anderson). The authors agree that it was this transnationalism that enabled the movement to retain its vibrancy until World War II and that anarchism's decline was due to specific historical circumstances. In the case of Baer, it was the ending of migration between Spain and 